UDC 630.266:631.445.4

\author{
A. A. LISNYAK ${ }^{1,2}$, docent, PhD., J. VILCEK ${ }^{3}$, prof., PhD., \\ S. TORMA ${ }^{3}, \mathrm{PhD}$. \\ ${ }^{I}$ V.N. Karazin Kharkiv National University, ecological faculty, 6 Svobody Sq., 61077, Ukraine, \\ e-mail: anlisnyak@gmail.com \\ ${ }^{2}$ Ukrainian Research Institute of Forestry and Forest Melioration named after G. M. Vysotsky, Pushkinska st. \\ 86, Kharkiv, 61024, Ukraine \\ ${ }^{3}$ National Agriculture and Food Centre, Soil Science and Conservation Research Institute, Regional workplace Prešov, \\ Raimonov st. 1, Prešov, 08001, Slovak Republic
}

\title{
AGRO-ECOLOGICAL EFFECT OF THE USE OF SLOWLY SOLVABLE CAPSULAR MINERAL FERTILIZERS IN FORESTRY AND AGRICULTURAL SECTOR
}

Purpose. Rationale for the use of slowly soluble encapsulated mineral fertilizers and establishing an assessment of the effectiveness of their use. Methods. Field, laboratory, analytical and mathematical. Results. The results of the field and analytical stages of studies on the use of slowly soluble encapsulated mineral fertilizers, improvement of the nitrogen and phosphorus-potassium regime of the soil, improving the efficiency of fertilizers in forestry and agriculture are presented. The positive effect of the use of the slowly soluble encapsulated mineral fertilizers of the Superagro on pine seedlings, spring wheat, potato and sugar beet has been established. Our research in open soil has found that the use of slowly soluble capsular form Superagro with the coating of granules with a biocquiel on the background without encapsulation Superagro ensure that $62 \%$ of the standard pine seedlings of the usual. We found that the encapsulated form of Superagro with pellets covered with biochemistry significantly increases the yield of crops, increases the quality of products and reduces the content of harmful substances. Yield of spring wheat, potatoes and sugar beet increased by $6.8 \%, 12.6 \%$ and $17.4 \%$ respectively. Conclusions. Our researches show, that capsulation of mineral fertilizers with the use of bio glue (furoplast), that means coverage of granules of fertilizers with thin layer with insignificant permeability, allows to increase considerably the productivity of cultures and to prolong the term of fertilizers' action in the soil. We have confirmed positive influence of the use of Superagro slowly solvable capsular mineral fertilizers on seedlings of an ordinary pine-tree, furious wheat, potato and sugar beet. All variants with capsular fertilizers have showed not only the increase of the productivity, but also amounts of dry matters, starch and decrease of amount of nitrates of the probed cultures. Conducted field researches confirm a positive agro-ecological effect of application of Superagro capsular form of fertilizers at coverage of their granules with furaplast.

Key words: slow-dissoluble fertilizers, bioadhesive coating, prolongation of fertilizers action, plants productivity, crop quality

Лісняк А. А. ${ }^{1,2}$, Вілчек Й. ${ }^{3}$, Торма С. ${ }^{3}$

${ }^{I}$ Украӥнський науково-дослідний інститут лісового господарства та агромеліораџії

імені Г. М. Висоцького

${ }^{2}$ Харківський наиіональний університет імені В. Н. Каразіна

${ }^{3}$ Науково-дослідний інститут трунтознавства та охорони трунтів, регіональний філіал в Прешов

АГРОЕКОЛОГІЧНИЙ ЕФЕКТ ВИКОРИСТАННЯ ПОВІЛЬНОРОЗЧИННИХ КАПСУЛЬОВАНИХ МІНЕРАЛЬНИХ ДОБРИВ В ЛІСОВОМУ ТА СІЛЬСЬКОМУ ГОСПОДАРСТВІ

Мета. Обгрунтування використання повільнорозчинних капсульованих мінеральних добрив та встановлення оцінки ефективності їх використання. Методи. Польовий, лабораторний, аналітичний та математичний. Результати. В умовах відкритого грунту встановлено, що використання повільнороз-чинної капсульованої форми Суперагро з покриттям гранул біоклеєм на фоні без капсулювання Суперагро забезпечує одержання $62 \%$ стандартних сіянців сосни звичайної. Максимальні прибавки в рості сіянців мали місце на варіанті з повільнорозчинною капсульованою формою Суперагро. Аналізуючи вплив Суперагро і його повільнорозчинної модифікації на сільськогосподарських культурах (ярова пшениця, картопля і цукровий буряк), виявлено що капсульована форма Суперагро з покриттям гранул біоклеєм значно збільшує урожайність сільськогосподарських культур, збільшує якість продукції та зменшує вміст шкідливих речовин. Врожайність ярової пшениці, картоплі і цукрового буряку збільшилися на 6,8 \%, 12,6 \% і 17,4 \% відповідно. При підживленні картоплі на варіанті з капсульованою формою Суперагро 
зростають показники вмісту сухих речовин та крохмалю, а вміст нітратів навпаки зменшується. При підживленні цукрового буряку на варіанті з капсульованою формою Суперагро зростають показники вмісту сухих речовин, а вміст нітратів навпаки зменшується. При цьому, вміст цукру на всіх варіантах залишається без змін. Досягти підвищення використання поживних елементів в добриві Суперагро можна на основі капсулювання, з застосуванням біоклею (фуропласту) і тим самим створити повільнорозчинні добрива з високими агрохімічними показниками. Підвищена вологостійкість поживних елементів в добриві Суперагро дозволяє розглядати капсульовані добрива як пролонговані, що діють не тільки в рік внесення, але і в наступні. 3 точки зору охорони навколишнього середовища, застосування добрив у вигляді капсульованих гранул може істотно знизити забруднення поверхневих і підземних вод від компонентів мінеральних добрив. Висновки. Капсулювання мінеральних добрив з застосуванням біоклею (фуропласту), тобто покриття гранул добрив тонкою плівкою із незначною проникністю, дозволяє значно підвищити врожайність культур та подовжити термін дії добрив у грунті. Підтверджено позитивний вплив використання повільнорозчинних капсульованих мінеральних добрив Суперагро на сіянці сосни звичайної, ярої пшениці, картоплі та цукрового буряку. Підтверджено позитивний агроекологічний ефект від застосування капсульованої форми добрив Суперагро при покритті їх гранул фурапластом.

Ключові слова: повільнорозчинні добрива, біоклейове покриття, пролонгування дії добрив, урожайність рослин, якість урожаю

Лисняк А. А. ${ }^{1,2}$, Вилчек Й. ${ }^{3}$, Торма С. ${ }^{3}$

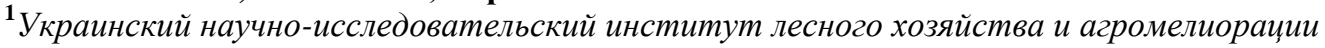

имени Г. Н. Высоикого,

${ }^{2}$ Харьковский национальный университет имени В. Н. Каразина

${ }^{3}$ Научно-исследовательский институт почвоведения и охраны почв, региональний филиал в Прешов

АГРОЭКОЛОГИЧЕСКИЙ ЭФФЕКТ ИСПОЛЬЗОВАНИЯ МЕДЛЕННО-РАСТВОРИМЫХ КАПСУЛИРОВАННЫХ МИНЕРАЛЬНЫХ УДОБРЕНИЙ В ЛЕСНОМ И СЕЛЬСКОМ ХОЗЯЙCTBE

Цель. Обоснование использования медленно-растворимых капсулированных минеральных удобрений и установления оценки эффективности их использования. Методы. Полевой, лабораторный, аналитический и математический. Результаты. В условиях открытого грунта установлено, что использование медленно-растворимых капсулированной формы Суперагро с покрытием гранул биоклея на фоне без капсулирования Суперагро обеспечивает получение 62\% стандартных сеянцев сосны обыкновенной. Максимальные прибавки в росте сеянцев имели место на варианте с медленно-растворимой капсулированной формой Суперагро. Анализируя влияние Суперагро и его медленно-растворимые модификации на сельскохозяйственных культурах (яровая пшеница, картофель и сахарная свекла), нами выявлено что капсулированная форма Суперагро с покрытием гранул биоклеи значительно увеличивает урожайность сельскохозяйственных культур, увеличивает качество продукции и уменьшает содержание вредных веществ. Урожайность яровой пшеницы, картофеля и сахарной свеклы увеличились на 6,8\%, 12,6\% и $17,4 \%$ соответственно. При подкормке картофеля на варианте с капсулированной формой Суперагро растут показатели содержания сухих веществ и крахмала, а содержание нитратов наоборот уменьшается. При подкормке сахарной свеклы на варианте с капсулированной формой Суперагро растут показатели содержания сухих веществ, а содержание нитратов наоборот уменьшается. При этом, содержание сахара на всех вариантах остается без изменений. Проведенные исследования показали, что добиться повышения использования питательных элементов в удобрении Суперагро можно на основе капсулирования, с применением биоклея (Фуропласт) и тем самым создать медленно-растворимые удобрения с высокими агрохимическими показателями. Повышенная влагостойкость питательных элементов в удобрении Суперагро позволяет рассматривать капсулированные удобрения как пролонгированные, действующих не только в год внесения, но и в последующие. С точки зрения охраны окружающей среды, применение удобрений в виде капсулированных гранул может существенно снизить загрязнение поверхностных и подземных вод от компонентов минеральных удобрений. Выводы. Капсулирования минеральных удобрений с применением биоклею (Фуропласт), то есть покрытие гранул удобрений тонкой пленкой с незначительным проницаемостью, позволяет значительно повысить урожайность культур и продлить срок действия удобрений в почве. Подтверждено положительное влияние использования медленнорастворимых капсулированных минеральных удобрений Суперагро на сеянцы сосны обыкновенной, яровой пшеницы, картофеля и сахарной свеклы.. Полевые исследования подтверждают положительный агроэкологический эффект от применения капсулированной формы удобрений Суперагро при покрытии их гранул фурапластом.

Ключевые слова: медленно-растворимые удобрения, биоклеевое покрытие, пролонгированное действие удобрений, урожайность растений, качество урожая 


\section{Introduction}

With the development of forest and agrarian production, we face more frequently the problem of providing the balanced use of nature: from one side, achievement of high increase of cultivated plants requires bringing of a certain set of fertilizers, from the other side, it is difficult to avoid contamination of the agro-eco system by surplus amount of these materials.

Numerous researches of world's scientists [1-4] are directed to minimization of negative influence of fertilizers on the natural environment with simultaneous achievement of the required norm of their provision for the cultivated plants. There are new types of fertilizers and modern agro technologies of their application, which are developed and inculcated in the forest and rural economy on the basis of these researches. However, despite this, the question of contamination of agro system by mineral fertilizers remains actual until now.

Therefore, we conduct the complex of researches on the search of new forms of mineral fertilizers, which would provide minimization of fertilizers' losses, and, consequently, minimization of their negative influence on agro-ecosystem. One of perspective ways of their creation is facing a cover of granules (capsules), which slows the process of transition of feeding elements into the soil ground [1]. The slowly solvable capsular form of fertilizer allows them to prolong their action for a significant amount of time, and therefore reduce their number and frequency of introduction, as well as the loss of nutrient elements in the environment [2]. Such encapsulated mineral fertilizers in their composition contain inhibitors with a changed solubility period, as well as a shell of organic or inorganic origin. The results of research on this problem, which are widely presented in the scientific literature, show the high agrochemical and ecological effectiveness of such capsular fertilizers of prolonged action [3-4].

Thus, the purpose of our researches was explanation of the use of slowly solvable capsular mineral fertilizers and estimation of efficiency of their use. Solution of the noted agroecological problems, which accompanies crea- tion and application of slowly solvable capsular mineral fertilizers, is an actual scientific direction, which contributes to improvement of soils' fertility and productivity of the grown plants, improvement of their biological quality, protection of environment from chemical pollution and degradation.

Nowadays, better conditions are required not only for the increase of production of industrial mineral fertilizers, but also to the increase of efficiency of their influence. A number of researchers have proved, that the greatest losses of elements of standard fertilizers happen with vertical and horizontal flows in the conditions of the washing water mode, and also in gaseous form in the first weeks after bringing into the soil $[4,5]$. In this case both in forest and agricultural economy slowly solvable fertilizers are perspective, and their use reduces the unproductive losses of feeding elements (first of all nitrogen). As compared to traditional fertilizers they can make 40-60\% [6, 7].

Numerous studies in different countries also recognize the effectiveness of such forms of mineral fertilizers and reduce their negative environmental impact on the environment (soils, groundwater, atmosphere, flora and fauna) due to the gradual release of nutrients during the vegetative period of plants $[8,9]$.

Despite the large number of film-forming materials developed [3, 7], the production of encapsulated mineral fertilizers is small, mainly for nitrogen fertilizers and only $0.4-0.5 \%$ in world production [6]. Such a small amount of production of encapsulated mineral fertilizers is associated with a significant increase in their value compared to conventional granular fertilizers, which is associated, first of all, with the cost of film-forming compositions. The promising way to increase the availability of encapsulated mineral fertilizers for their use in mass agricultural production is the use of polymer waste and the improvement of coating technology. Polymer waste of industrial origin is recycled, as a rule, directly at enterprises, and household polymer waste that could be used as a part of film-forming compositions, virtually completely falls into landfills of solid household waste [9]. 


\section{Methods of researches}

Theoretical methods were used in the process of researches, namely: collection and description of facts, their analysis. Empiric methods stipulated conduction of the field and laboratory researches on the base of Regional workplace Prešov of the Soil Science and Conservation Research Institute (Slovakia Republic). Laboratory analytical researches were conducted with implementation of ISO standardized methods of measurements. Processing and generalization of experimental data were executed with the help of computer equipment and application software.

Production of slowly solvable fertilizers was carried out with physical method by put- ting cover-up matter on their granules. The capsular method was tested on Superagro NPK fertilizer (15:15:15) with application of bio glue (furaplast), capable to create on granules a semi-permeable membrane at drying up and to slow considerably the solubility of mineral fertilizer. Fertilizer's granules were covered with $60 \%$ solution of furaplast in acetone 0,8 $1,2 \%$ percent from the mass of fertilizer.

Superagro Fertilizer and its slowly solvable modification were brought while sowing of pine-trees' seedlings at the basic bringing (during the cultivating before sowing), for agricultural cultures - on sowing (furious wheat) and feeding (potato, sugar beet).

\section{Results of researches}

In conditions of the opened soil our researches showed, that the use of Superagro slowly solvable capsular formula with coverage of granules with bio glue on the background without capsulation of Superagro provides $62 \%$ of standard seedlings of an ordinary pine-tree (on control $-9 \%$, without capsulation of Superagro - $28 \%$ ) (Table 1). Maximal increases in growth of seedlings were

noted with the use of Superagro slowly solvable capsular formula.

This can be explained by the fact, that kinetics of freeing of nourishing elements from the granules of Superagro slowly solvable capsular formula stipulates more continuous consumption of nourishing elements by fertilizer seedlings, along with this stress situations for plants are avoided.

Table 1

Effect of Superagro NPK fertilizers (15:15:15) and its slowly soluble modification at the main (under pre-sowing cultivation) introduction of the growth of annual pine seedlings

\begin{tabular}{|c|c|c|c|c|c|c|c|c|c|}
\hline \multirow[t]{3}{*}{ Variant } & \multirow{2}{*}{\multicolumn{2}{|c|}{$\begin{array}{c}\text { Average } \\
\text { height }\end{array}$}} & \multicolumn{6}{|c|}{ Weight of seedlings (average) } & \multirow{3}{*}{$\begin{array}{c}\text { Output } \\
\text { of stand } \\
\text { seed- } \\
\text { lings, \% }\end{array}$} \\
\hline & & & \multicolumn{2}{|c|}{ terrestrial } & \multicolumn{2}{|c|}{ underground } & \multicolumn{2}{|c|}{ of all } & \\
\hline & centimeter & $\%$ & grams & $\%$ & grams & $\%$ & grams & $\%$ & \\
\hline No fertilizer & $7,9 \pm 0,31$ & 100 & $0,22 \pm 0,008$ & 100 & $0,10 \pm 0,004$ & 100 & 0,32 & 100 & 9 \\
\hline $\mathrm{N}_{15} \mathrm{P}_{15} \mathrm{~K}_{15}$ & $9,4 \pm 0,35$ & 120 & $0,23 \pm 0,007$ & 105 & $0,12 \pm 0,003$ & 120 & 0,33 & 103 & 28 \\
\hline $\begin{array}{l}\text { Capsulated } \\
\mathrm{N}_{15} \mathrm{P}_{15} \mathrm{~K}_{15}\end{array}$ & $10,6 \pm 0,49$ & 134 & $0,33 \pm 0,011$ & 165 & $0,15 \pm 0,006$ & 150 & 0,48 & 150 & 62 \\
\hline $\mathrm{SSD}_{0,5}$ & 0,4 & & 0,02 & & 0,01 & & & & \\
\hline
\end{tabular}

On analyzing the influence of Superagro and its slowly solvable modification on agricultural cultures (spring wheat, potato and sugar beet), we discovered, that Superagro capsular form with coverage of granules with bio glue considerably increases the productivity of agricultural cultures, increases quality of products and diminishes content of harmful matters. So, from the table 2 it becomes evident, that the productivity of spring wheat, potato and sugar beet has increased on $6,8 \%, 12,6 \%$ and $17,4 \%$ accordingly.

Feeding of potato with Superagro capsular form results in increase of the indexes of content of dry matters and starch, and the content of nitrates decreases consequently (Table 3). So, in the variant of non- capsular Superagro the content of nitrates is $178 \mathrm{mg} / \mathrm{kg}$ of raw matter, but in the variant of capsular form of Superagro - $154 \mathrm{mg} / \mathrm{kg}$ of raw matter.

On feeding of sugar beet with the capsular form of Superagro, the indexes of content of dry matters increase, and content of nitrates decreases consequently (Table 4). So, in the variant of non capsular Superagro content of nitrates makes $408 \mathrm{mg} / \mathrm{kg}$ of raw matter, and in the variant of capsular form of Superagro - 
Table 2

Influence of Suprago NPK (15:15:15) and its slowly soluble modification on yield of crops

\begin{tabular}{|l|c|c|c|c|}
\hline \multirow{2}{*}{ Culture } & \multicolumn{2}{|c|}{ Yield in variants, h/hectare } & \multicolumn{2}{c|}{ Increase productivity } \\
\cline { 2 - 5 } & $\mathbf{N}_{\mathbf{1 5}} \mathbf{P}_{\mathbf{1 5}} \mathbf{K}_{\mathbf{1 5}}$ & $\begin{array}{c}\text { Encapsulated } \\
\mathbf{N}_{\mathbf{1 5}} \mathbf{P}_{\mathbf{1 5}} \mathbf{K}_{\mathbf{1 5}}\end{array}$ & $\mathbf{h} / \mathbf{h e c t a r e}$ & $\mathbf{\%}$ \\
\hline Spring wheat & 47,1 & 50,3 & 3,2 & 6,8 \\
\hline Potato & 437 & 492 & 55 & 12,6 \\
\hline Sugar beet & 396 & 465 & 69 & 17,4 \\
\hline
\end{tabular}

Table 3

Influence of Suprago NPK (15:15:15) and its slowly soluble modification on the quality of potatoes

\begin{tabular}{|c|c|c|c|c|c|c|}
\hline \multirow[b]{2}{*}{ Variant } & \multicolumn{3}{|c|}{ Fractional composition, \% } & \multirow{2}{*}{$\begin{array}{c}\text { The content } \\
\text { of dry } \\
\text { matter, \% }\end{array}$} & \multirow{2}{*}{$\begin{array}{c}\text { Starch } \\
\text { content, \% }\end{array}$} & \multirow{2}{*}{$\begin{array}{c}\text { Nitrate } \\
\text { content, } \\
\text { mg/kg of } \\
\text { raw matter }\end{array}$} \\
\hline & is great & average & small & & & \\
\hline $\mathrm{N}_{15} \mathrm{P}_{15} \mathrm{~K}_{15}$ & 59,3 & 28,1 & 12,6 & 22,15 & 17,64 & 178 \\
\hline $\begin{array}{l}\text { Capsulated } \\
\mathrm{N}_{15} \mathrm{P}_{15} \mathrm{~K}_{15}\end{array}$ & 68,1 & 27,2 & 5,7 & 24,42 & 17,98 & 154 \\
\hline
\end{tabular}

Table 4

Influence of Supergragon NPK (15:15:15) and its slowly soluble modification on the quality of sugar beet

\begin{tabular}{|c|c|c|c|}
\hline Variant & $\begin{array}{c}\text { Absolutely dry matter, } \\
\text { h/ha }\end{array}$ & The content of sugar & $\begin{array}{c}\text { Nitrate content, mg/kg } \\
\text { of raw matter }\end{array}$ \\
\hline $\mathrm{N}_{15} \mathrm{P}_{15} \mathrm{~K}_{15}$ & 93 & 16,8 & 408 \\
\hline Capsulated $\mathrm{N}_{15} \mathrm{P}_{15} \mathrm{~K}_{15}$ & 125 & 16,9 & 342 \\
\hline
\end{tabular}

$342 \mathrm{mg} / \mathrm{kg}$ of raw matter. Thus, content of sugar in all these variants remains unchangeable.

The conducted researches witnessed, that achievement of increase of the use of nourishing elements in Superagro fertilizer is possible on the basis of capsulation, with the use of bio glue (furoplast) and at the same time it helps to create slowly solvable fertilizers with high agricultural chemistry indexes. Increased moisture resistance of nourishing elements in Superagro fertilizer allows to consider capsular fertilizers as prolonged, that remain active not only during the first year of bringing but also in the followings years. From the point of environmental protection, application of fertilizers in the form of capsular granules can substantially reduce contamination of superficial and underground waters from the components of mineral fertilizers. A number of scien- tists define that fertilizers' capsulation also allows to decrease their remaining and water absorbance, and also to solve the question of transportation of fertilizers in embankment. Thus, different bio glue matters can be used for capsulation [9-11]. In many works, mechanisms of the influence of slowly soluble fertilizer forms on agrochemical properties of soils, increase of productivity of agricultural and forest crops, and also on the quality of the obtained products are recognized $[11,12]$.

In the case of use instead of traditional types of fertilizers encapsulated, in Ukraine it would be possible to reduce the introduction of fertilizers into the soil (subject to the unchanged effect of fertilizing) by 568 thousand tons - $16 \%$ of the total amount of fertilizers used in the forestry and agriculture of Ukraine annually (Fig. 1). 


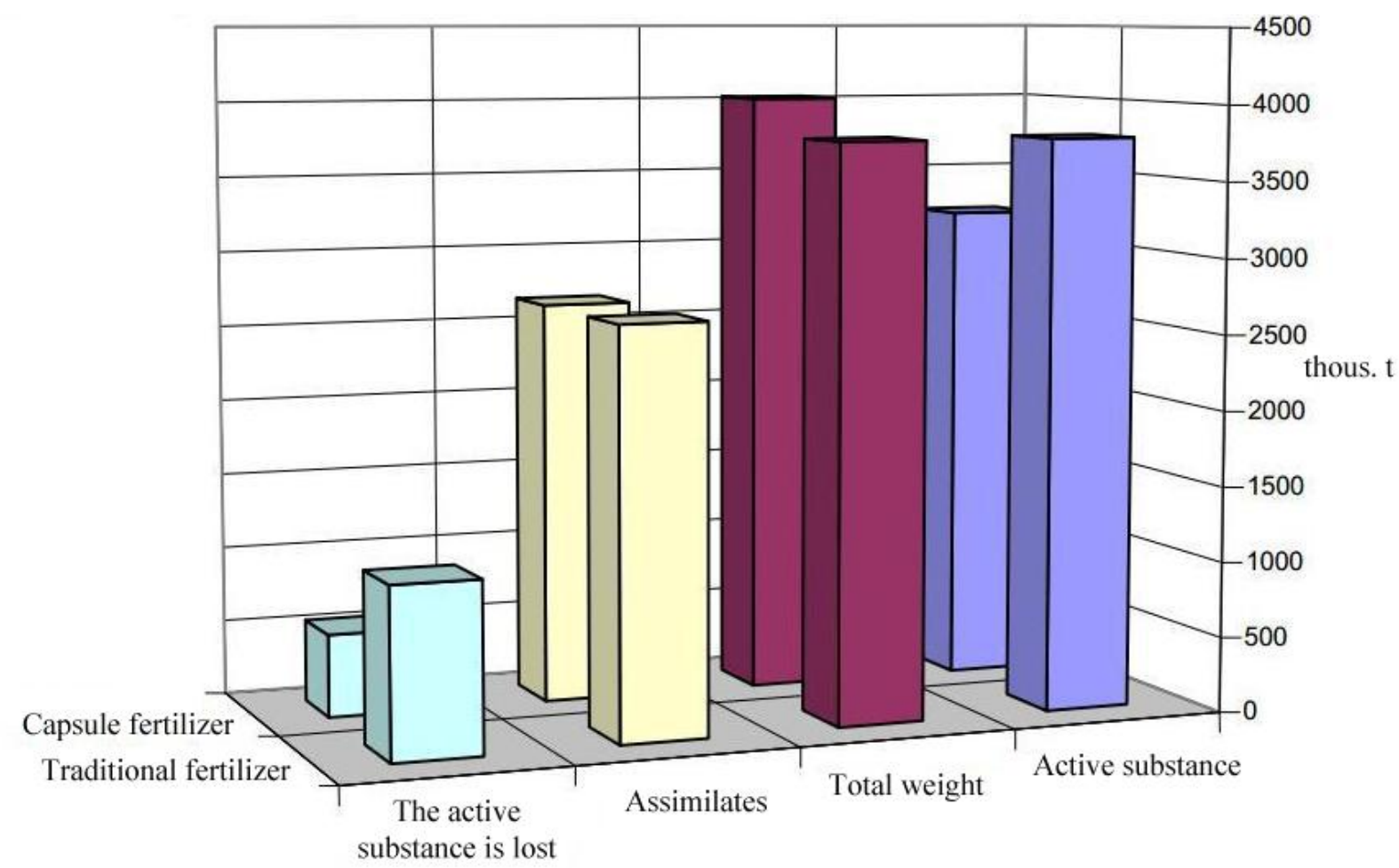

Fig.1 - Comparative characteristics of the use of capsulated and traditional fertilizers in Ukraine

\section{Conclusions}

Our researches show, that capsulation of mineral fertilizers with the use of bio glue (furoplast), that means coverage of granules of fertilizers with thin layer with insignificant permeability, allows to increase considerably the productivity of cultures and to prolong the term of fertilizers' action in the soil. We have confirmed positive influence of the use of Superagro slowly solvable capsular mineral fertilizers on seedlings of an ordinary pine- tree, furious wheat, potato and sugar beet. All variants with capsular fertilizers have showed not only the increase of the productivity, but also amounts of dry matters, starch and decrease of amount of nitrates of the probed cultures. Conducted field researches confirm a positive agro-ecological effect of application of Superagro capsular form of fertilizers at coverage of their granules with furaplast.

\section{Лimepamypa}

1. Господаренко Г. М. Основи інтегрованого застосування добрив. К.: ЗАТ НІЧЛАВА, 2002. $344 \mathrm{c.}$

2. Нагурський О. А., Мальований М. С., Бунько В. Я. Особливості капсулювання гранульованих мінеральних добрив в апаратах киплячого шару. Хімічна промисловість України. 2012. №5. С. 55-58.

3. Малюга Ю. Е. Эффективность применения медленно растворимого аммофоса на эродированной почве под мелиоративные насаждения. Вісн. Харків. нач. аграр. ун-ту. Сер. «Грунтознавство і агрохімія, землеробство, лісове господарство». 2005. Вип. №1. С. 166-168.

4. Скрильник Є. Органо-мінеральні добрива: перспективи їхнього застосування. Пропозиція. 2010. №12 C. 68-70.

5. Лісняк А. А. Лісотипологічна оцінка еродованих грунтів на різних материнських породах в умовах різних природних зон України. Вісник ХНУ ім. Каразіна. Серія Екологія . 2015, Випуск 12, № 1147. С. 14-20. ISSN 1992-4259.

6. Огліх В. В. Виробництво і застосування мінеральних добрив як вагомий фактор підвищення врожайності. Економіка АПК. 2012. №2. С. 38-43. 
7. Малюга Ю. Е. , Смольянинов И.И., Дегтярев В. В. Окклюдированные удобрения: их возможности для повышения качественной структуры урожая. Агрохімія і грунтознавство [«Грунти - Екологія продовольство»], Х., 1998. С. 180-181.

8. Наукові та прикладні основи захисту грунтів від ерозії в Україні [Текст]: монографія / Д. О. Тімченко, М. М. Гічка, М. В. Куценко, А. А. Лісняк [та інші]. Харків: НТУ "ХПІ", 2010. - 460 с. - ISBN 978-966-593-820-0

9. Нагурський О. А. Капсульовані мінеральні добрива. Кінетика вивільнення компонентів із полідисперсних сумішей. Хімічна промисловість України. 2012. №3 (110). С. 69-73.

10. Таран А. Л. Эффективные технологии капсулирования гранул азотсодержащих удобрений. $X u$ мическая промышленность сегодня. 2003. №7. С. 5-10.

11. Мальований М. С. , Нагурський О. А., Бунько В. Я., Друзюк В. М. Тепломасообмін процесу капсулювання мінеральних добрив водним розчином плівкоутворюючої композиції палигорськіт- меляса. Вісник Кременчуцьького НУ ім. Михайла Остроградського. 2012. №2 (74). С. 117-120.

12. Barna I., Gumnytskyi Y., Atamanyuk V. Intradiffusion mass transfer during drying of slag gravel raw granule. Chemistry \& Chemical Technology. 2013. Vol. 7, №4. P. 461-465.

\section{References}

1. Hospodarenko H. M. (2002). Osnovy intehrovanoho zastosuvannya dobryv. [Fundamentals of Integrated Use of Fertilizers]. Kyiv: ZAO NICHLAWA. 344. [in Ukrainian].

2. Nahurs'kyy O. A., Mal'ovanyy M. S., Bun'ko V. Ya.(2012). Osoblyvosti kapsulyuvannya hranul'ovanykh mineral'nykh dobryv $\mathrm{v}$ aparatakh kyplyachoho sharu. [Features of capsulation of granular mineral fertilizers in the apparatus of a fluidized bed]. Chemical Industry of Ukraine. 5. 55-58. [in Ukrainian].

3. Malyuga YU. E. (2005). EHffektivnost' primeneniya medlenno rastvorimogo ammofosa na ehrodirovannoj pochve pod meliorativnye nasazhdeniya.[Efficiency of the use of slowly soluble ammophos on eroded soil under meliorative plantations ]. Kharkiv Bulletin. nats. agrar. the university. - Series "Soil Science and Agrochemistry, Agriculture, Forestry". 1. 166-168. [in Russian].

4. Skryl'nyk Ye. (2010). Orhano-mineral'ni dobryva: perspektyvy yikhn'oho zastosuvannya. [Organomineral fertilizers: prospects for their application]. Proposal. 12. 68-70. [in Ukrainian].

5. Lisnyak A. A. (2015). Lisotypolohichna otsinka erodovanykh gruntiv na riznykh materyns'kykh porodakh v umovakh riznykh pryrodnykh zon Ukrayiny. [Forest-typological estimation of eroded soils on different maternal rocks under conditions of different natural zones of Ukraine]./ Visnyk of V.N.Karazin Kharkin national university. Series Ecology. . 1147(12). 14-20. ISSN 1992-4259. [in Ukrainian].

6. Ohlikh V. V. (2012). Vyrobnytstvo i zastosuvannya mineral'nykh dobryv yak vahomyy faktor pidvyshchennya vrozhaynosti. [Production and application of mineral fertilizers as a significant factor in increasing yields ]. Economy of the agroindustrial complex. 2. 38-43. [in Ukrainian].

7. Malyuga YU. E. , Smol'yaninov I.I., Degtyarev V. V. (1998). Okklyudirovannye udobreniya: ih vozmozhnosti dlya povysheniya kachestvennoj struktury urozhaya. [Occluded fertilizers: their potential for improving the qualitative structure of the crop]. Interdepartmental thematic scientific collection Agrochemistry and Soil Science [Soils - Ecology - Food]. P. 180-181. [in Russian].

8. Timchenko D. O., Hichka M. M., M. V. Kutsenko, A. A. Lisnyak [ta inshi] (2010). Naukovi ta prykladni osnovy zakhystu hruntiv vid eroziyi v Ukrayini.[ Scientific and Applied Fundamentals of Soil Protection from Erosion in Ukraine]. Kharkiv: NTU "KhPI". 460/ ISBN 978-966-593-820-0 [in Ukrainian].

9. Nahurs'kyy O. A. (2012). Kapsul'ovani mineral'ni dobryva. Kinetyka vyvil'nennya komponentiv iz polidyspersnykh sumishey. [Capsulated mineral fertilizers. Kinetics of the release of components from polydisperse mixtures]. Chemical industry of Ukraine. 3 (110). 69-73. [in Ukrainian].

10. Taran A. L. (2003). EHffektivnye tekhnologii kapsulirovaniya granul azotsoderzhashchih udobrenij.[Effective technologies of capsulation of granules of nitrogen-containing fertilizers]. Chemical industry today. 7. 5-10. [in Russian].

11. Mal'ovanyy M. S. , Nahurs'kyy O. A., Bun'ko V. Ya., Druzyuk V. M. (2012). Teplomasoobmin protsesu kapsulyuvannya mineral'nykh dobryv vodnym rozchynom plivkoutvoryuyuchoyi kompozytsiyi palyhors'kitmelyasa. [Heat-mass transfer of the process of encapsulation of mineral fertilizers by aqueous solution of the film-forming composition of paligorskyt-molase ]. Transactions of Kremenchuk Mykhailo Ostrohradskyi National University. 2 (74). 117-120. [in Ukrainian].

12. Barna, I., Gumnytskyi, Y., Atamanyuk, V. (2013). Intradiffusion mass transfer during drying of slag gravel raw granule. Chemistry \& Chemical Technology. 7(4). 461-465. [in English].

Надійшла до редколегії 08.09.2017 